\title{
DIAGNOZA TRANSFORMACJI ARCHITEKTONICZNO-BUDOWLANEJ ZASOBÓW MIESZKANIOWYCH XIX I XX WIEKU WYBRANYCH MIAST GÓRNEGO ŚLĄSKA
}

\begin{abstract}
Tematem artykułu jest stan zasobów architektury mieszkaniowej okresu 18482013 wybranych miast Górnego Śląska w ujęciu przeprowadzonych zmian architektoniczno-budowlanych. Zmiany architektoniczno-budowlane przeprowadzone w badanych zasobach mieszkaniowych są istotnym miernikiem oceny tychże zasobów przez ich użytkowników. Zmiany ujęto w trzy aspekty: techniczny, funkcjonalny i estetyczny. Głównym celem badań jest prezentacja szczegółowej oceny i kompleksowego obrazu stanu zasobów mieszkaniowych wybranych miast Górnego Śląska, opartych o próby statystyczne, liczne analizy rozwiązań przestrzennych w ujęciu ewolucyjnym rozwoju form górnośląskiej architektury mieszkaniowej. Dla większej czytelności i precyzji uzyskanych informacji, przeprowadzana ocena związana jest $\mathrm{z}$ bezpośrednią prywatną przestrzenią mieszkania $\mathrm{i} w$ ograniczonym stopniu jedynie porusza modernizacje i przekształcenia przestrzeni sąsiedzkiej lub tzw. strefy przydomowej. Zakres czasowy obejmuje lata 1848-2013. Datą otwierającą jest rok 1848. Zakres terytorialny obejmuje współcześnie zdefiniowany obszar siedmiu górnośląskich miast: Gliwic, Zabrza, Bytomia, Raciborza, Rudy Śląskiej, Katowic i Tychów. Praca podejmuje próbę uzyskania odpowiedzi na pytanie: jakim zmianom ulegała substancja badanych zasobów mieszkaniowych? W jakich okresach użytkowania zmiany te były najintensywniejsze lub największe (zarówno w historycznym ujęciu jak i w ujęciu fazy użytkowej
\end{abstract}

Słowa kluczowe: modernizm, budownictwo mieszkaniowe, rewitalizacja, Górny Śląsk, studium przypadku, architektura mieszkaniowa, renowacja

\section{Wprowadzenie}

W literaturze przedmiotu poświęconej architekturze mieszkaniowej podejmowana najczęściej jest problematyka środowiska zbudowanego, problematyka nowych trendów projektowych i form, często w kontekście rozwoju zrównoważonego. Coraz częściej znajduje się również opracowania opisujące i analizujące

${ }^{1}$ Jerzy Cibis, Politechnika Śląska, Wydział Architektury, ul. Akademicka 7, 44-100 Gliwice; tel.: 601416 400; e-mail: j.cibis@ interia.pl 
zagadnienia socjologicznej perspektywy zamieszkiwania. Na tle wieloletnich publikacji P. Szafera, ukazujących znaczny dorobek polskiego mieszkalnictwa, oraz szczegółowych podręczników projektowania architektury mieszkaniowej, autorstwa m.in. W. Korzeniewskiego, zaczęły pojawiać się kolejne prace i artykuły poświęcone analizie form architektonicznych autorstwa m.in.: A. Błażko i M. Skrzypek-Łachińskiej oraz J. Pallado. Ważnymi pozycjami na temat przestrzeni miastai mieszkalnictwa są publikacje Gyurkovicha J.: Architektura w przestrzeni miasta. Wybrane problemy, Politechnika Krakowska, Kraków 2010 oraz „Miejskość miasta”, Wydawnictwo P.K. z 2007 roku Adama Nadolnego poruszającego problematykę zdrowia i higieny w tym środowisku, Sławomira Gzella „O Architekturze. Szkice pisane i rysowane” Wydawnictwa BlueBind z 2014 roku, prace Anny Agaty Kantarek „O prywatności” z 2007 roku oraz „Evora - dwa miejskie środowiska zamieszkania” z 2010 roku.

Wśród pozycji literatury zagranicznej niewątpliwie należy wspomnieć wydawnictwa powstałej w 1964 roku grupy badawczej S.A.R. (Stichting Architecten Research), podejmującej problematykę partycypacji społeczeństwa w procesie projektowania mieszkań, z czasem rozszerzoną o działania badawcze procesów industrializacji i typizacji budownictwa mieszkaniowego. Do tych opracowań należy zaliczyć "Brief Outline of the SAR Principles and Methodology" oraz Dimension and Position of Material: Modular Coordination". Należy wspomnieć również o twórczości przedstawicieli szkoty frankfurckiej z jej współtwórcą Theodorem W. Adorno i jego manifestem „Teoria estetyczna” [4]. Tuż przed wybuchem II wojny światowej niemiecki inżynier i architekt Ernst Neufert opublikował znaczącą pozycję „Podręcznik projektowania architektonicznego" (Bauentwurfslehre, 1936), będącą do dzisiaj skarbnicą informacji o ilości przestrzeni niezbędnej do wykonywania jakiejkolwiek czynności życiowej. „O procesie cywilizacji" Norberta Eliasa, „Mimesis. Rzeczywistość przedstawiona w literaturze Zachodu" Ericha Auerbacha, „Czas, przestrzeń, architektura" Sigfrieda Giediona czy „Pionierzy współczesności" Nikolausa Pevsnera to również fundamentalne pozycje traktujące o nowym spojrzeniu na problematykę nowej architektury w ujęciu interdyscyplinarnym. W latach pięćdziesiątych i sześćdziesiątych coraz większy wpływ na projektowanie miały również nauki społeczne, przyrodnicze oraz statystyka. Christopher Alexander w książce „Notes on the Synthesis of Form” (Uwagi o syntezie formy) poszukuje abstrakcyjnych zasad rozwiązywania problemów projektowych, zdefiniowanych jako wymagania, które musza zostać spetnione [5].

Pomimo tak licznej i wartościowej literatury oraz wielu prowadzonych w przeciągu ostatnich kilkunastu lat badań naukowych brakuje prac prezentujących kompleksowy stan zasobów mieszkaniowych, kształtowanych na przestrzeni stuleci w ujęciu oceny potrzeb użytkowników opartej na predyspozycji i realnych działaniach modernizacyjnych. Takie ujęcie tematu, w znacznej mierze oparte na metodach badawczych wykorzystujących raporty 
statystyczne przeprowadzanych zmian $\mathrm{w}$ badanej substancji pozwoliłoby na możliwie najbliższą realiom ocenę zasobów mieszkalnych i potencjału związanego $\mathrm{z}$ ich dalszym wykorzystaniem. Ponadto, artykuł jest szerokim ujęciem i niejako podsumowaniem działalności w obszarze badań podejmowanym przez autorów $\mathrm{w}$ dotychczasowych licznych artykułach, publikacjach [1-6].

Datą otwierającą jest 1848 rok. W połowie XIX wieku zaczęła się kształtować świadomość potrzeby kompleksowego rozwiązywania narastających problemów mieszkaniowych, zapoczątkowanych wiele lat wcześniej przez rewolucję przemysłową i gwałtownie zmieniającą się sytuację społeczno-ekonomiczną w Europie. Masowość problemu braku zadowalającej przestrzeni mieszkalnej, związana z migracjami ludności ze wsi do miast, zmuszała do sięgnięcia po rozwiązania także masowe. Przemysł zainicjował proces rozwoju wielu ówczesnych miast. Rok 1848 był w wielu przypadkach datą przełomową wydarzeń i procesów zachodzących nie tylko na arenie politycznej Europy. Wybuch masowych protestów i demonstracji zwany popularnie Wiosna Ludów, w połączeniu z wyjątkowo ciężką zimą (1847/1848), epidemią cholery w wielu rejonach Europy (w tym głównie na Górnym Śląsku - o czym informują m.in. archiwalia Raciborza i Bytomia) stał się momentem kulminacyjnym do podjęcia administracyjnych decyzji leżących u podstaw poprawy warunków socjalno-bytowych lokalnej ludności. To właśnie w 1848 roku zniesiono zobowiązania służebne chłopów na Śląsku, otwierając tym samym możliwości przekształcania się chłopstwa w klasę robotniczą. Dlatego też w tym okresie umiejscowić należy pierwsze na Górnym Śląsku realizacje kolonii robotniczych (Zabrze, następnie Bytom i Gliwice), a więc podejmowane próby kompleksowego rozwiązania nasilającej się kwestii głodu mieszkaniowego. Datą zamykającą zakres czasowy jest rok 2013 - jako możliwie najbardziej współczesny okres realizacji kolejnych zasobów mieszkaniowych, podlegających ocenie.

Zakres terytorialny obejmuje współcześnie zdefiniowany obszar siedmiu górnośląskich miast: Gliwic, Zabrza, Bytomia, Raciborza, Rudy Śląskiej, Katowic i Tychów. Wybór taki został podyktowany potrzebą przeanalizowania istotnych czynników kształtujących poszczególne ośrodki miejskie. Mamy bowiem do czynienia zarówno z miastami o genezie średniowiecznej (Gliwice, Bytom, Racibórz), aglomeracjami osad i kolonii przemysłowych (Zabrze, Ruda Śląska, Katowice), jak i wreszcie ośrodkami powstałymi na mocy decyzji planistycznych (tzw. Nowe Tychy). Interesujące również wydaje się zestawienie zasobów mieszkaniowych realizowanych w okresie 1919-1945 pod odmienną jurysdykcją: niemiecką (Gliwice, Zabrze, Bytom, Racibórz) i polską (Ruda Śląska, Katowice, Tychy). Sama lokalizacja wybranych miast jako ośrodków Górnego Śląska podyktowana została w dużej mierze znajomością problematyki i charakterystyki tego terenu, jako obszaru wieloletnich badań naukowych, analiz oraz działalności projektowej autora. 


\section{Metodologia badań}

W pracy zastosowane zostały metody wykorzystywane $\mathrm{w}$ architekturze, a także naukach społecznych, tj. badania literaturowe (literatura przedmiotu, źródła ikonograficzne), badania układów architektonicznych (wizje lokalne, sporządzanie dokumentacji fotograficznej oraz analiza wybranych rozwiązań architektonicznych), studia porównawcze oraz badania ankietowe (studium przypadków przeprowadzone przez ankietyzację). Konstrukcja badań zbliżona jest do grupy badań jakościowych POE - a dokładniej Building Performance Evaluation BPE (ocena sprawności budynku; ocena wykonania obiektu, odnosząca się do wszystkich faz cyklu ich życia, począwszy od planowania, przez fazę użytkowania, a następnie etapy zmian adaptacyjnych i dalej do wyburzenia i utylizacji włącznie). Zastosowano także metody analizy opisowej i metodę porównawczą. Jako metodę badawczą wybrano studium przypadku (case study) $\mathrm{z}$ uwagi na wszechstronność jej stosowania w architekturze, możliwość wielowątkowości prowadzonych badań oraz jej elastyczność w interpretacji wyników badań. Zdaniem autora bezpośredni użytkownicy środowiska mieszkaniowego są najczulszym markerem artykułującym swoje wymagania, potrzeby, trwałość założeń architektonicznych i socjologicznych oraz świadomość estetyczną i technologiczną. Zakres wprowadzonych przez nich zmian w obrębie mieszkania jako wybranego fragmentu środowiska zbudowanego zilustruje wszelkie pozytywne i negatywne rozwiązania, charakterystyczne dla danego okresu po dzień dzisiejszy. Struktura przeprowadzonych badań została oparta na tezach Stewarta Branda, głoszonych w publikacji wydanej w 1995 roku pt. How Buildings Learn. What Happens after they're Built181. Brand w swojej ksiażce przedstawia teorie przemian budynku i 6 markerów badawczych, jakimi są warstwy budynku: działka, konstrukcja, powłoka, instalacje, podziały funkcjonalne i wyposażenie. Brand w swej teorii uznaje podmiotowość człowieka jako użytkownika środowiska zbudowanego, co wywołało liczne kontrowersje w środowisku architektów. Podkreśla rolę służebności architektury jako sztuki użytkowej podporządkowanej odbiorcy (w tym wypadku użytkownikom, czyli lokatorom) oraz nie uznaje budynków jako dzieł sztuki, mających dawać splendor i uznanie ich twórcom. Uważa również, że budynek jest organizmem podlegającym stałym przemianom i przekształceniom wraz ze zmieniającymi się potrzebami człowieka pod wpływem ciągłości postępu technicznego, technologicznego, a także zmianą stylu życia, mody oraz zmianami ortogenetycznym. Poniżej przedstawiono zmodyfikowaną wersję rysunku Branda, pokazującą relację pomiędzy czasem użytkowania poszczególnych warstw, określoną jako „,cykl życia budynku" (rys. 1.). 


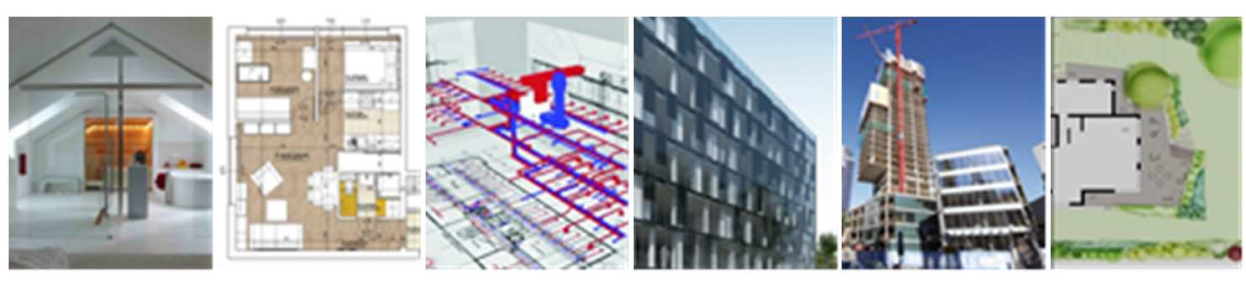

\begin{tabular}{|c|c|c|c|c|c|}
\hline WYPOSAŻENIE & $\begin{array}{c}\text { UKŁAD } \\
\text { PRZESTRZENN }\end{array}$ & INSTALACJE & POWŁOKA & KONSTRUKCJA & DZIALKA \\
\hline 6 MIESIĘCY & $3-5$ LAT & $8-10$ LAT & $10-25$ LAT & $50-100$ LAT & „WIECZNA" \\
\hline
\end{tabular}

Rys. 1. Warstwy budynku wg Stewarda Branda

Fig. 1. Building layers acc. to Stewart Brand

Brand bardzo precyzyjnie określił również zależności branżowe i multidyscyplinarną formułę projektu architektoniczno-budowlanego oraz zachodzące interakcje pomiędzy odbiorcami bezpośrednimi, czyli użytkownikami a użytkowanym obiektem, co pokazują poniższe tabele, opracowane na potrzeby prowadzonych badań i ukazujące schematy czasowe, a także procesy, którym w sposób naturalny podlega substancja mieszkaniowa. Pokazuje również wagę podjętego problemu w kontekście zróżnicowanych cykli życia mających wpływ na nowe gałęzie nauki, takie jak facility management czy building development, projektowanie zrównoważone oraz sektory kredytowe w bankowości. Z opisanych cykli użytkowych wynika również fakt, iż nie warto oszczędzać na najtrwalszych elementach budynku, np. konstrukcji, jako struktury najbardziej trwałej zaraz po działce i warto ją zaprojektować jako strukturę adaptowalną i elastyczną, umożliwiającą wprowadzanie zmian użytkowych trudnych do przewidzenia na etapie realizacji inwestycji.

\section{Pytania badawcze}

Badania podejmują próbę uzyskania odpowiedzi na pytanie: jakim zmianom ulegała substancja badanych zasobów mieszkaniowych? W jakich okresach użytkowania zmiany te były najintensywniejsze lub największe (w ujęciu zarówno historycznym, jak i w fazie użytkowania)? Czy odnotowane zmiany są zbieżne z opracowanymi przez innych autorów wartościami podlegającymi wymiarom trwałości i czasu (a więc: wyposażenie, podziały wnętrz, instalacje, fasada, konstrukcja)? I wreszcie, które układy - w opinii użytkowników - są ponadczasowe, podlegając przemianom w najmniejszym stopniu lub odznaczają się największą możliwością adaptacji? 


\section{Zmiany techniczne zasobów mieszkaniowych}

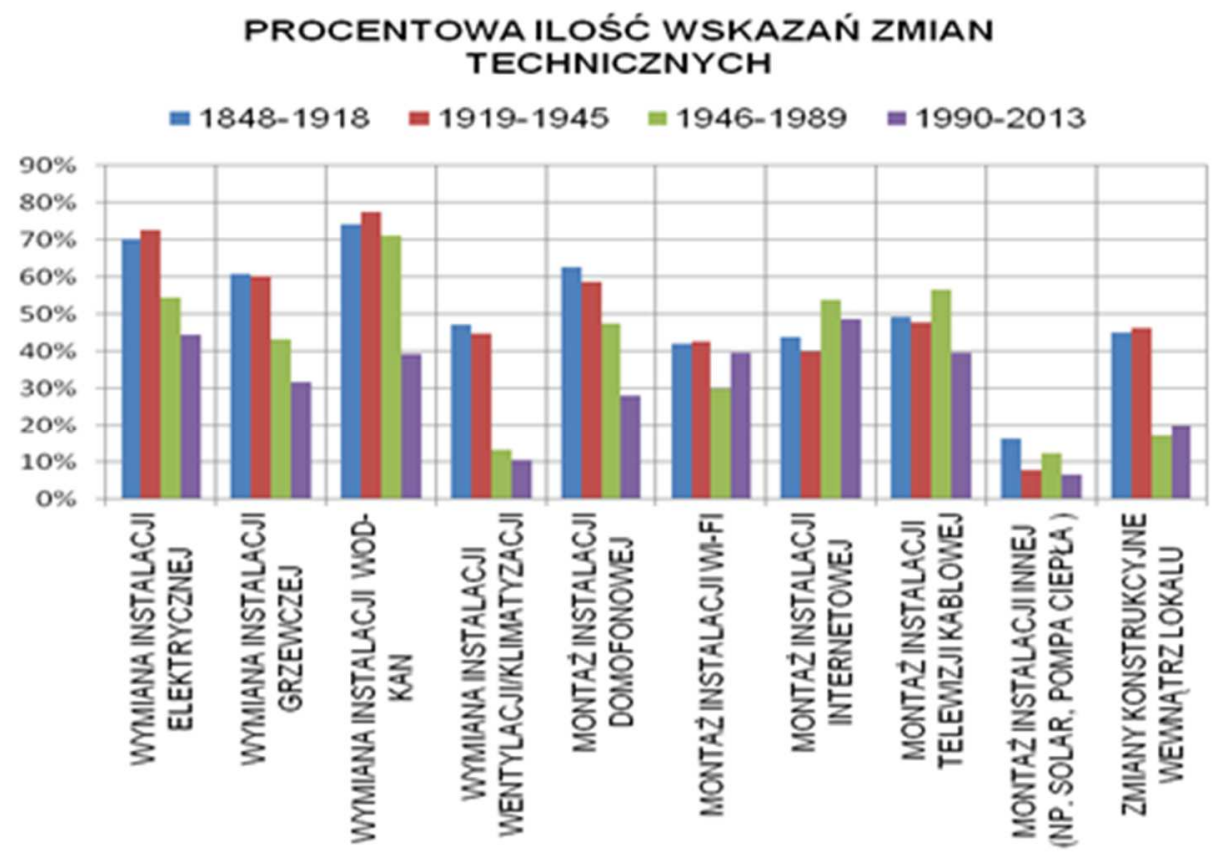

Rys. 2. Procentowa liczba wskazań zmian technicznych ogółem w budynkach z wybranych lat

Fig. 2. Percentage number of indications of technical changes in buildings, in total, in selected years

Powyższy wykres (rys. 2.) obrazuje nam zakres i charakter zmian technicznych przeprowadzonych na badanym zbiorze lokali w poszczególnych okresach. Uwagę zwraca liczba wymian, w szczególności instalacji elektrycznej i wod.kan. w budynkach z lat 1946-1989, jako stosunkowo nowych. W starszych okresach oczywiste zdaje się być techniczne zużycie i modernizacje w ramach zmian funkcjonalnych. Również zmiany w instalacji wentylacji można wytłumaczyć tym samym faktem zużycia technicznego starszych obiektów. Zrównoważona liczba wskazań w zakresie montażu instalacji internetowej, wi-fi, telewizji kablowej świadczy o ciągłym procesie doposażenia mieszkań w instalacje niskoprądowe, służące przekazowi informacji wizualnych, akustycznych i da-nych cyfrowych, mających na celu podnoszenie standardu mieszkań do obowiązujących trendów wyposażenia. Zaskakującym elementem wydaje się być doposażanie mieszkań w ekologiczne źródła energii, szczególnie tych z lat 1848-1918 oraz 1945-1989. W pierwszym wypadku dotyczy to obiektów zabytkowych, które trafiając w ręce zamożnych inwestorów zostają poddane gruntownemu procesowi rewitalizacji w ramach wykształconej mody. Drugi przypadek to również coraz częściej poszukiwanie alternatywnej formy pozyskiwania ciepła 
dla dużych skupisk mieszkaniowych, co podyktowane jest ekonomiką użytkowania oraz zasadnością techniczną ich stosowania.

\section{Zmiany funkcjonalne zasobów mieszkaniowych}

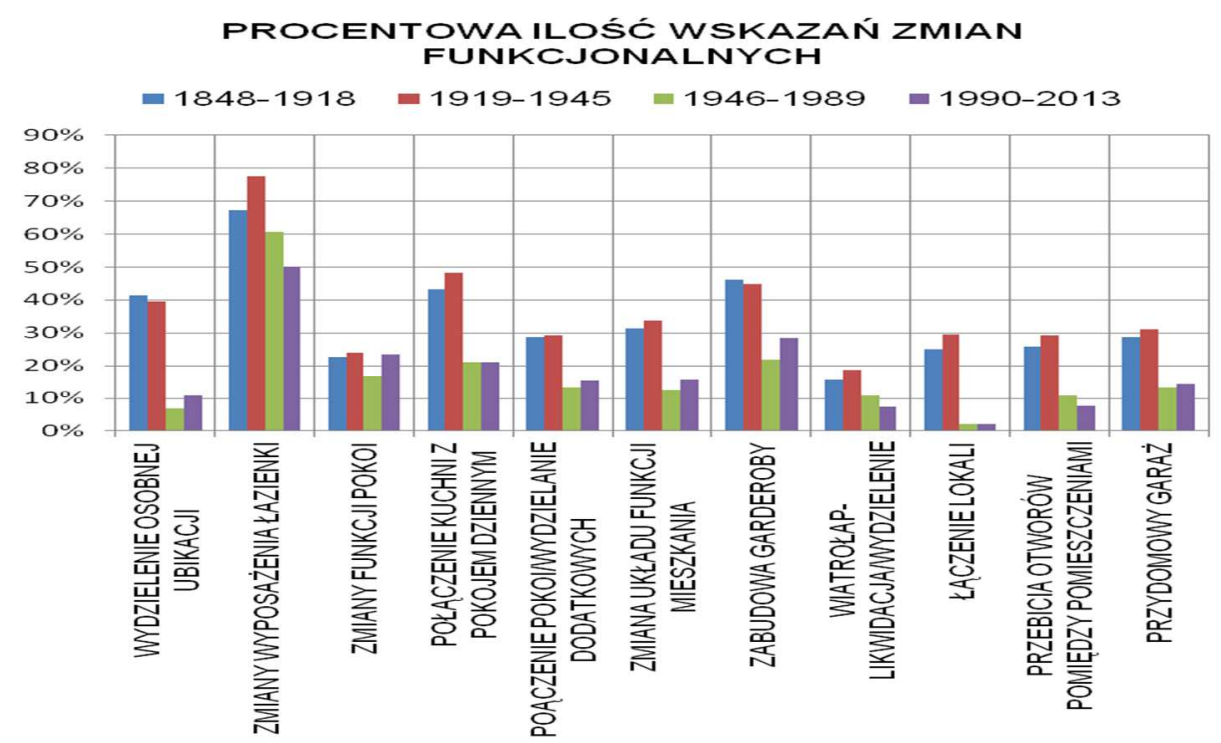

Rys. 3. Procentowa liczba wskazań zmian funkcjonalnych ogółem w wybranych okresach

Fig. 3. Percentage number of indications of functional changes, in total, in selected periods

Przedstawione w formie wykresu (rys. 3.) wskazania respondentów obrazują zakres niespełnionych oczekiwań respondentów w stosunku do zamieszkiwanego lokalu, co obrazuje zakres zmian przez nich wprowadzonych w czasie zamieszkiwania lub bezpośrednio po momencie zakupu. Dominują zmiany wprowadzane w przestrzeni sanitarnej mieszkań, co związane jest archetypami obowiązującymi w danym okresie budowy lokalu lub nieodpowiednim wyposażeniu lub układzie funkcjonalnym. Wydzielanie osobnej ubikacji dotyczy mieszkań z lat 1848-1918, gdzie często ubikacja lokalizowana była poza budynkiem lub w latach późniejszych na półpiętrze. W latach 1919-1945 standardem było lokalizowanie pomieszczeń sanitarnych na półpiętrze poza obrębem mieszkania wraz z pomieszczeniem gospodarczym. Zmiana funkcji pokoi, a także łączenie izb również dotyczy lokali z tego okresu, z uwagi na niski standard powierzchniowy, wynikający z przeznaczenia tych lokali w tamtym czasie dla napływającej ludności wiejskiej do miast, z uwagi na rozwój przemysłu ciężkiego (tzw. kolonie robotnicze lub wcześniej siedlungi). Najczęściej spotykanym działaniem w sferze zmian funkcjonalnych w strefie dziennej jest łączenie kuchni (kiedyś występowała wyłącznie jako wydzielone zamknięte pomieszczenie) ze strefą 
dzienną, a więc pokojem dziennym lub jadalnią, która coraz częściej pojawia się jako wydzielona przestrzeń funkcjonalna. Początkowo, w latach 80 . połączenie to miało postać okienka podawczego pomiędzy kuchnią i pokojem dziennym, $\mathrm{z}$ czasem przekształciło się $\mathrm{w}$ formę pełnej integracji tych dwu funkcji na bazie zagranicznych wzorców mieszkaniowych.

\section{Zmiany estetyczne zasobów mieszkaniowych}

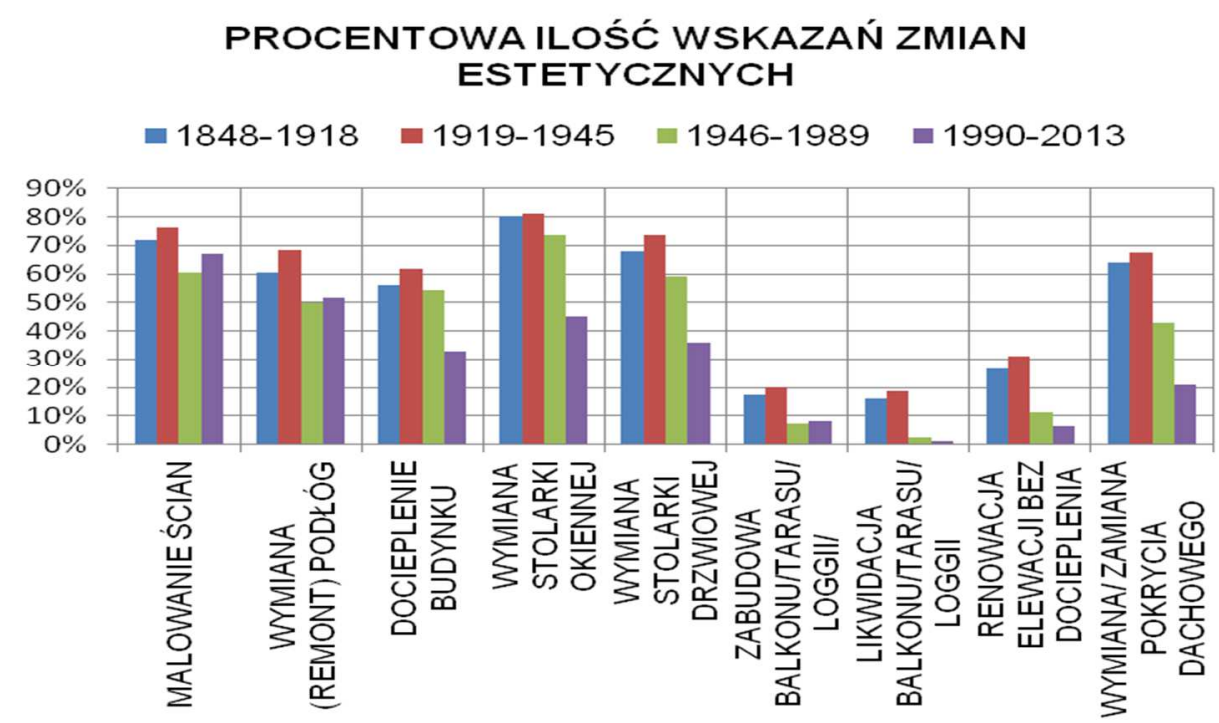

Rys. 4. Procentowa liczba wskazań zmian estetycznych ogółem w wybranych okresach (opr. aut.)

Fig. 4. Percentage number of indications of aesthetic changes, in total, in selected periods (authors' study)

Wykres wskazań obrazujących zmiany estetyczne zachodzące w strukturach mieszkaniowych uwidacznia sposób percepcji bezpośredniego otoczenia użytkownika lokalu, braków estetycznych i wizualnych, a także świadomości estetycznej mieszkańców (rys. 4.). Zgodnie ze stopniem zużycia technicznego mieszkań dominują prace związane z utrzymaniem komfortu estetycznego, a więc wymiana stolarki drzwiowej i okiennej oraz pokrycia, ewentualnie wymiany materiałów przekrycia dachu. Wewnątrz lokali najczęściej mamy do czynienia z normalnymi pracami związanymi ze zużyciem technicznym warstw, a więc remontem podłóg i malowaniem ścian mieszkania. Również działania na elewacji budynku wydają się wynikać z normalnej eksploatacji lokalu oraz coraz ostrzejszych parametrów cieplnych stawianych lokalom mieszkalnym, zgodnie z polityką energooszczędności w całej gospodarce. Zwiększona częstotliwość występowania działań w strefach loggi i tarasów w obiektach starszych (lata 1848-1918 oraz 1919-1945) wynika ze złej jakości technicznej ich wykonania, 
adaptacji na ogrody zimowe oraz bufory termiczne, a także możliwości powiększania strefy dziennej. Poniższe zestawienia zbiorcze są graficzną prezentacją wyników badań danych na bazie przeprowadzonej ankiety (rys. 5-6). Są one podstawą do sformułowania wniosków końcowych, mających charakter porównawczy w celu określenia cech charakterystycznych dla każdego zbioru danych bazując na założonych okresach powstania zasobów, a także zakresach prac modernizacyjnych dla całego badanego czasookresu. Przyjmując strukturę czasową jak podstawę badań można wyróżnić charakterystyczne elementy, cechujące każdy z badanych zbiorów.
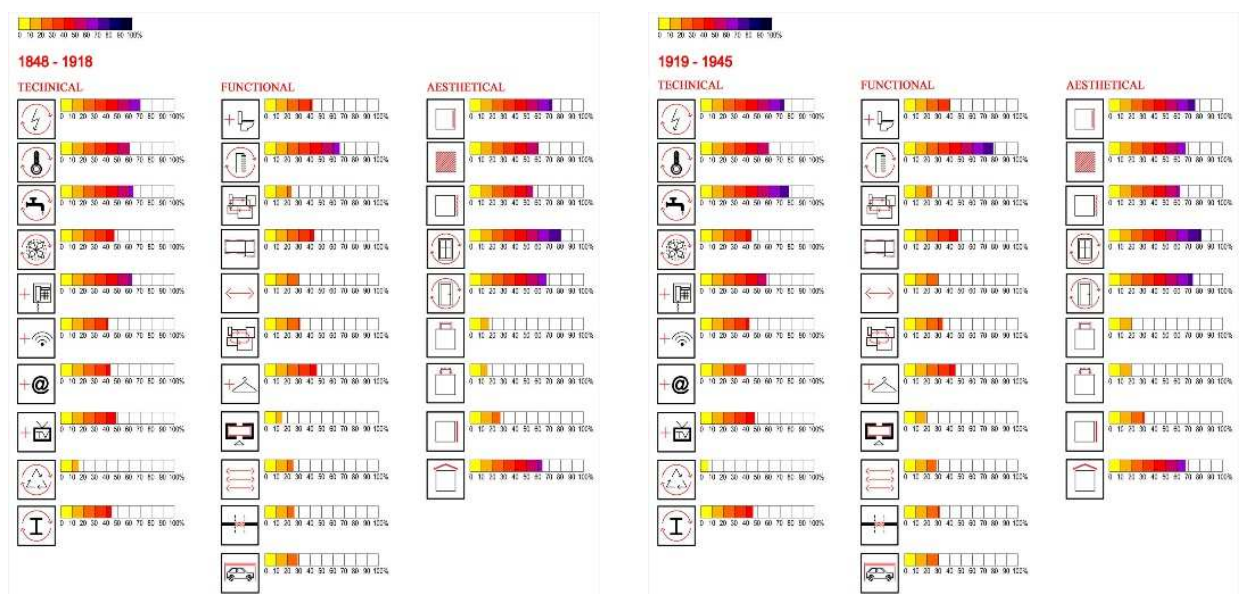

Rys. 5. Zestawienie zbiorcze działań modernizacyjnych w latach 1848-1945

Fig. 5. Collective comparison of the examined modernization actions in the years1848-1918

Zasoby $z$ lat 1848-1918 $\mathrm{w}$ sferze zmian technicznych podlegały przede wszystkim pracom modernizacyjnym $\mathrm{w}$ zakresie wymian instalacji $\mathrm{z}$ uwagi na ich naturalne zużycie eksploatacyjne, wprowadzanie nowych rozwiązań instalacyjnych w miejsce przestarzałych rozwiązań. Przyczyn tego stanu rzeczy można doszukiwać się w fakcie, że coraz częściej właścicielami lokali z tego okresu są osoby zamożne, z uwagi na ich lokalizację w centrach miast lub śródmiejskich kwartałach, co czyni je atrakcyjnymi na rynku nieruchomości. W grupie zmian funkcjonalnych działań modernizacyjnych tego okresu dominują prace w przestrzeni sanitarnej mieszkań oraz wydzielanie garderoby jako odrębnej funkcji w przestrzeni wejściowej. Zmiany estetyczne zdominowane są wszelkimi pracami dotyczącymi powłok poziomych i pionowych.

Również w latach 1919-1945 zasoby mieszkaniowe w sferze zmian technicznych podlegały przede wszystkim pracom modernizacyjnym $\mathrm{w}$ zakresie wymian instalacji, z uwagi na ich naturalne zużycie eksploatacyjne. Druga grupą 
prac modernizacyjnych to aktualizacja wyposażenia technicznego mieszkań w instalacje charakterystyczne dla współczesnego budownictwa, takie jak domofon, Internet, wi-fi, telewizja kablowa oraz ekologiczne źródła ciepła. Grupa zmian funkcjonalnych obejmuje przede wszystkim działania w przestrzeni sanitarnej mieszkań oraz zmian funkcji w obrębie poszczególnych izb, a także połączenie kuchni z pokojem dziennym.

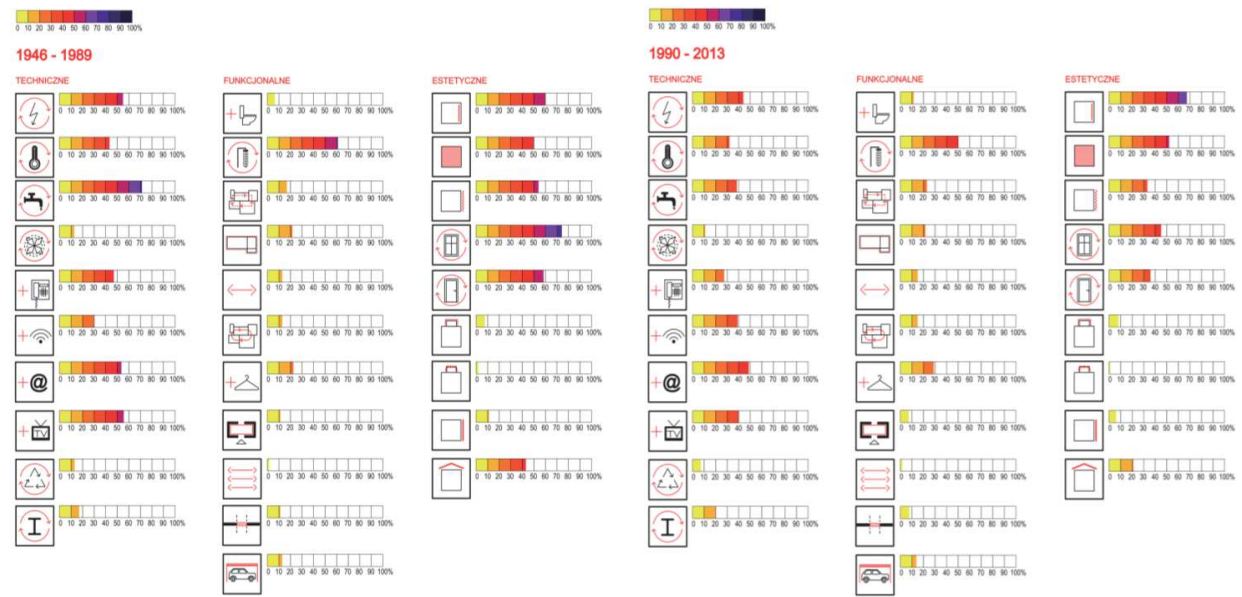

Rys. 6. Zestawienie zbiorcze działań modernizacyjnych w latach 1946-2013

Fig. 6. Collective comparison of the examined modernization actions in the years1946-2013

Lata 1946-1989 to dominacja wielkiej ptyty co ma odzwierciedlenie we wszystkich grupach prac. W sferze działań technicznych wyróżnić można remonty sieci elektrycznej (wymiana instalacji aluminiowej na miedzianą) i wodociągowej (najczęściej wymiana na PVC i PE), a także aktualizacja wyposażenia technicznego mieszkań w instalacje charakterystyczne dla współczesnego budownictwa, takie jak domofon, Internet, wi-fi, telewizja kablowa. Zanikają tutaj zmiany konstrukcyjne $\mathrm{z}$ uwagi na problemy techniczne przy wszelkiego rodzaju perforacji ścian. Działania w sferze funkcjonalnej ograniczają się do przestrzeni sanitarnych, natomiast sfera estetyczna zawęża się do bieżących prac remontowych wewnątrz mieszkań (malowanie ścian i podłóg) oraz wymiany stosowanej w tym okresie typowej stolarki okiennej (drewnianej) na „plastiki” oraz również typowej stolarki drzwiowej najczęściej wykonanej z płyty pilśniowej malowanej w kolorze białym.

Zasoby mieszkaniowe datowane na lata 1990-2013, jak obrazuje powyższe zestawienie, również podlegają procesom modernizacyjnym, jednak ich struktura ma charakter działań eksploatacyjnych. Coraz częściej jest to również związane z funkcjonującą formą własności lokalu jako najmu. Wynika ona ze 
wzrastających ruchów migracyjnych ludności do dużych ośrodków miejskich w poszukiwaniu pracy, zmiennego w czasie statusu rodziny (narodziny dziecka, bogacenie się społeczeństwa, awans społeczny i finansowy), postrzeganie mieszkań jako formy inwestycji kapitałowej (zyski z najmu lokalu, lokata wolnego kapitału) oraz braku instrumentów finansowych dla młodych małżeństw i osób rozpoczynających samodzielną egzystencje (niskooprocentowane kredyty mieszkaniowe, programy mieszkaniowe dla młodych). Ingerencje w infrastrukturę techniczną mieszkań polegają głównie na rozbudowie o nowe podłączenia coraz bardziej skomplikowanych urządzeń AGD głównie związanych ze strefą kuchni, dlatego dotyczą instalacji elektrycznej i wodno-kanalizacyjnej. W grupie zmian funkcjonalnych dominują dalej działania w strefie sanitarnej, związane również z wymianą i rozbudową wyposażenia łazienki (coraz częściej montowany bidet, elektryczna suszarka, wymiana wanien na prysznic i odwrotnie, wanny asymetryczne, jacuzzi, parawany wannowe). Przemianom ulega również strefa wejściowa, gdzie pojawia się garderoba wejściowa w formie zabudowanej (zabudowa wnęk, szafy wbudowane, pawlacz) lub otwartej

\section{Konkluzje}

Biorąc pod uwagę aktualne, wysokie wymagania mieszkańców i oczekiwania rynku nieruchomości mieszkaniowych oraz rosnące i zmienne w czasie potrzeby użytkowników, współczesny architekt powinien być zarówno projektantem, jak i badaczem opracowywanego tematu. Zaproponowany model projektanta-badacza, który wyposażony w odpowiednią wiedzę i narzędzia może stosować je w codziennej praktyce projektowej, a jego warsztat jest wzbogacony o metody bezpośredniego pozyskiwania informacji oraz wiedzy pochodzącej ze środowiska zbudowanego i od jego użytkowników może znacząco wpłynąć na jakość projektowania realizowanych obiektów i sukces inwestycji. Przedstawione przykłady, głęboko zakorzenione w lokalnej tradycji budowlanej i mieszkaniowej, charakterystyczne dla miejsca i czasu ich powstawania w kontekście zróżnicowanych warunków politycznych, socjologicznych i historycznych, dają pełen obraz wartości semiotyki znaków, materiałów, detali i układów funkcjonalnych, stanowiący o walorach lokalnego środowiska zbudowanego w ujęciu historycznym.

\section{Literatura}

[1] Stichting Architecten Research, "Dimension and Position of Material: Modular Coordination", Eindhoven, Netherlands, 1973.

[2] B. Leupen, C. Grafe, N. Korning., M. Lampe, P. De Zew, "Projektowanie architektury w ujęciu analitycznym", Wydawnictwo Śląsk, 2012, s. 113-115. 
[3] J. Cibis, "The identification of the architectural-construction changes in residential stock from 1848-2013“, Wydaw. Politechniki Śląskiej, pp. 253, 2015.

[4] T. W. Adorno, "Aesthetic Theory", Wydawnictwo PWN, Warszawa, 1994

[5] C. Alexander, "Notes on the Synthesis of Form", paperback, 224 pages, Harvard University Press, 1964

[6] B. Nowogońska, "Proposal for determining the scale of renovation needs of residential buildings" Civil and Environmental Engineering Reports No. 22, pp. 137-144, 2016

\section{DIAGNOSIS OF TRANSFORMATION IN ARCHITECTURE AND CONSTRUCTION OF THE HOUSING STOCK IN THE YEARS 1848- 2013 IN SELECTED CITIES OF UPPER SILESIA.}

\section{S u m m a r y}

The subject of the work is the state of residential architecture resources of the period 18482013 selected cities of Upper Silesia, changes carried out in the architecture and construction. Changes to the architecture and construction carried out in the test is an important evaluation measure of housing resources these resources by their users. The changes are contained in three aspects: technical, functional and aesthetic. The main objective of the work is the presentation of a detailed assessment and comprehensive picture of the state of the housing stock of selected cities in Upper Silesia, based on statistical tests, numerous spatial solutions in terms of the evolutionary development of forms of residential architecture in Upper Silesia. For increased readability and precision of the information received, the assessment is linked to a direct private space and to a limited extent only moves and upgrades to transform neighbourhood space or socalled backyard area. Time covers the period 1848-2013.Opening date is the year 1848. The territorial scope of area-defined today includes seven Silesian cities: Gliwice, Zabrze, Bytom, Racibórz, Ruda Śląska, Katowice and Tychy. The work attempts to answer the question: what were the changes in the substance of the housing stock? In which periods were these changes most intense or largest (both in historical terms and in terms of the use)?

Keywords: Upper Silesia; modernism; architectural heritage; residential structure; architectural transformation; statistical report; case study; technical condition

Przestano do redakcji: 09.06.2017 r.

Przyjęto do druku: 01.09.2017 r. 